\title{
Habitat suitability, threats and conservation strategies of Hump-nosed Pit Viper Hypnale hypnale Merrem (Reptilia: Viperidae) found in Western Ghats, Goa, India
}

\author{
Nitin S. Sawant ${ }^{1}$, Trupti D. Jadhav ${ }^{2} \&$ S.K. Shyama ${ }^{3}$ \\ ${ }^{1}$ Research Scholar, ${ }^{3}$ Reader, Department of Zoology, Goa University, Goa 403206, India \\ ${ }^{2}$ H.No. 359-A, St.Inez, Altinho, Panaji, Goa 403001, India \\ Email: ${ }^{1}$ nitinnature@yahoo.co.in
}

Date of publication (online): 26 October 2010 Date of publication (print): 26 October 2010 ISSN $0974-7907$ (online) | 0974-7893 (print)

Editor: Gernot Vogel

\section{Manuscript details:}

Ms \# 02490

Received 22 June 2010

Final received 29 September 2010

Finally accepted 03 October 2010

Citation: Sawant, N.S., T.D. Jadhav \& S.K Shyama (2010). Habitat suitability, threats and conservation strategies of Hump-nosed Pit Viper Hypnale hypnale Merrem (Reptilia: Viperidae) found in Western Ghats, Goa, India. Journal of Threatened Taxa 2(11): 1261-1267.

Copyright: (c) Nitin S. Sawant, Trupti D. Jadhav \& S.K. Shyama 2010. Creative Commons Attribution 3.0 Unported License. JoTT allows unrestricted use of this article in any medium for non-profit purposes, reproduction and distribution by providing adequate credit to the authors and the source of publication.

Author Details: NITIN S. SAWANT employed with WWF-India, as State Director of the Goa State office, with responsibilities of designing, planning and executing environmental awareness and conservation programme in the state and to address issues pertaining to environment and wildlife. Actively involved in rescue operations of snakes and other wild animals in association with the forest department of Goa.

TRUPTI D. JADHAV founder member of Nirmiti, a local NGO working towards documentation of biodiversity and its conservation. Pursued MSc in zoology through Goa University. Presently involved in wildlife conservation activities.

DR. S.K. SHYAma, Associate Professor, Department of Zoology, Goa University.

Author Contribution: NSS and TDJ have contributed in the field work and writing of the manuscript. SKS contributed in the final editing of the manuscript.

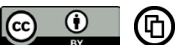

OPEN ACCESS | FREE DOWNLOAD
Abstract: Recent studies indicate that most species are best conserved in their natural community, which results in niche conservation. Depletion of any species is an irreversible change. In the present study the habitat ecology, threats and conservation strategies for the Hump-nosed Pit Viper Hypnale hypnale are suggested. The present study was undertaken in some protected areas (PAs) of Goa and the cashew plantations adjoining these PAs. $H$. hypnale prefers cool and moist places; most of the females of this species are found to spend the period from post monsoon to late summer in the cashew plantations adjoining and within the PAs, making them more susceptible to anthropogenic threats. We conclude that this pattern of seasonal changes in habitat use is mostly a consequence of niche conservation. However, this preference for a particular micro-habitat emphasizes the importance for the conservation of this snake population and although the most suitable habitat in the Western Ghats, for this species is included in the protected areas, specific guidelines are needed to assess conservation needs.

Keywords: Conservation, Goa, habitat, Hypnale hypnale, threats, Western Ghats.

\section{INTRODUCTION}

The habitat of a species can be defined as that portion of a multidimensional hyperspace (defined by any number of habitat factors) that is occupied by a given species (Whitaker et al. 1973). Data pertaining to interspecific niche partitioning by snakes has lagged behind that of other vertebrate groups, notably lizards and birds (Schoener 1977; Toft 1985). Descriptions of the preferred habitat is currently available for very few snake species (Reinert 1993) therefore, snakes are not well represented in studies of habitat selection. This is partly due to their secretive nature. They are difficult to locate and sightings are probably biased in favor of habitats where they are most visible. Measures of habitat suitability need to evaluate micro-habitat usage and animal movement patterns (Gurnell et al. 2002). Studies on some snake species suggest that individual snakes do actively select a preferred portion of their environment (Reinert 1984; Weatherhead \& Charland 1985; Burger \& Zappalorti 1988; Weatherhead \& Prior 1992) and the habitat selection is influenced by complex biotic and abiotic factors (Reinert 1993). Although some species are highly specialized and can exploit a narrow range of habitat, most taxa utilize a broader range, at least occasionally (Heatwole 1977). Thus, it is also important to understand why species shift among habitat type.

The State of Goa is located along the central west coast of India, lying between latitude $14^{0} 51^{\prime}-15^{\circ} 48^{\prime} \mathrm{N} \& 73^{\circ} 41^{\prime}-74^{0} 20^{\prime} \mathrm{E}$, with an area of $3702 \mathrm{~km}^{2}$. The forests of Goa have been classified into various types which include the west coast tropical evergreen, cane brakes, wet bamboo brakes, west coast semi-evergreen, moist bamboo brakes, lateritic semi-evergreen forest, slightly moist teak forest, southern moist deciduous forest, southern secondary moist mixed deciduous forest, south Indian sub-tropical hill savannah woodland, southern sub tropical hill forest, lateritic scrub and dry tropical river rain forest 


\section{(Champion \& Seth 1968)}

The Hump-nosed Pit Viper belongs to Family Viperidae and Subfamily Crotalinae. Three species of pit vipers are found in Goa viz. Trimeresurus malabaricus, Trimeresurus gramineus and Hypnale hypnale (Khaire 2006; Pradhan 2008; Sawant et al. 2010). Out of these three species T. malabaricus is endemic to the Western Ghats, $T$. gramineus is reported from Eastern and Western Ghats and Hypnale hypnale is found in the Western Ghats and Sri Lanka (Smith 1943; Whitaker 1978). Whereas H. hypnale has been recorded mainly from the southern part (up to about $16^{\circ} \mathrm{N}$ ) of the Western Ghats and Sri Lanka (Smith 1943; Murthy 1990; Maduwage et al 2009), Maduwage et al. (2009) found no differences in specimens from the Western Ghats and from Sri Lanka.

The $H$. hypnale is both terrestrial and semi-arboreal in habit (Murthy 1990). The protected areas in Goa cover most of the Western Ghats region. The Goa region occupies about $2 \%$ of the total area of the Western Ghats
(Joshi \& Janarthanam 2004). The forests of the Western Ghats are very rich in wildlife and endemic species (Gadgil \& Guha 1992). Many reptiles in the Western Ghats have restricted distribution, which is a major reason for many of them (63 Species) being threatened (Kumar et al. 1998). Despite high endemism and threat, there are only a few studies on the habitat preferences and community structure of reptiles in the Western Ghats (Inger et al. 1987; Bhupathy \& Kannan 1997). The Western Ghats of south India have experienced large scale changes over the last century because of expansion and urbanisation (Nair 1991). Many of the world's species are threatened due to habitat destruction and fragmentation, which is the major cause of species endangerment (Dodd 1987; Mittermeier et al.1992; Wilson 1992; Losos et al. 1995; Fahrig 1997). Understanding the components of a snake's spatial and habitat ecology, such as movement patterns and habitat selection are therefore important in identifying features necessary for the preservation of a species (Dodd 1987,

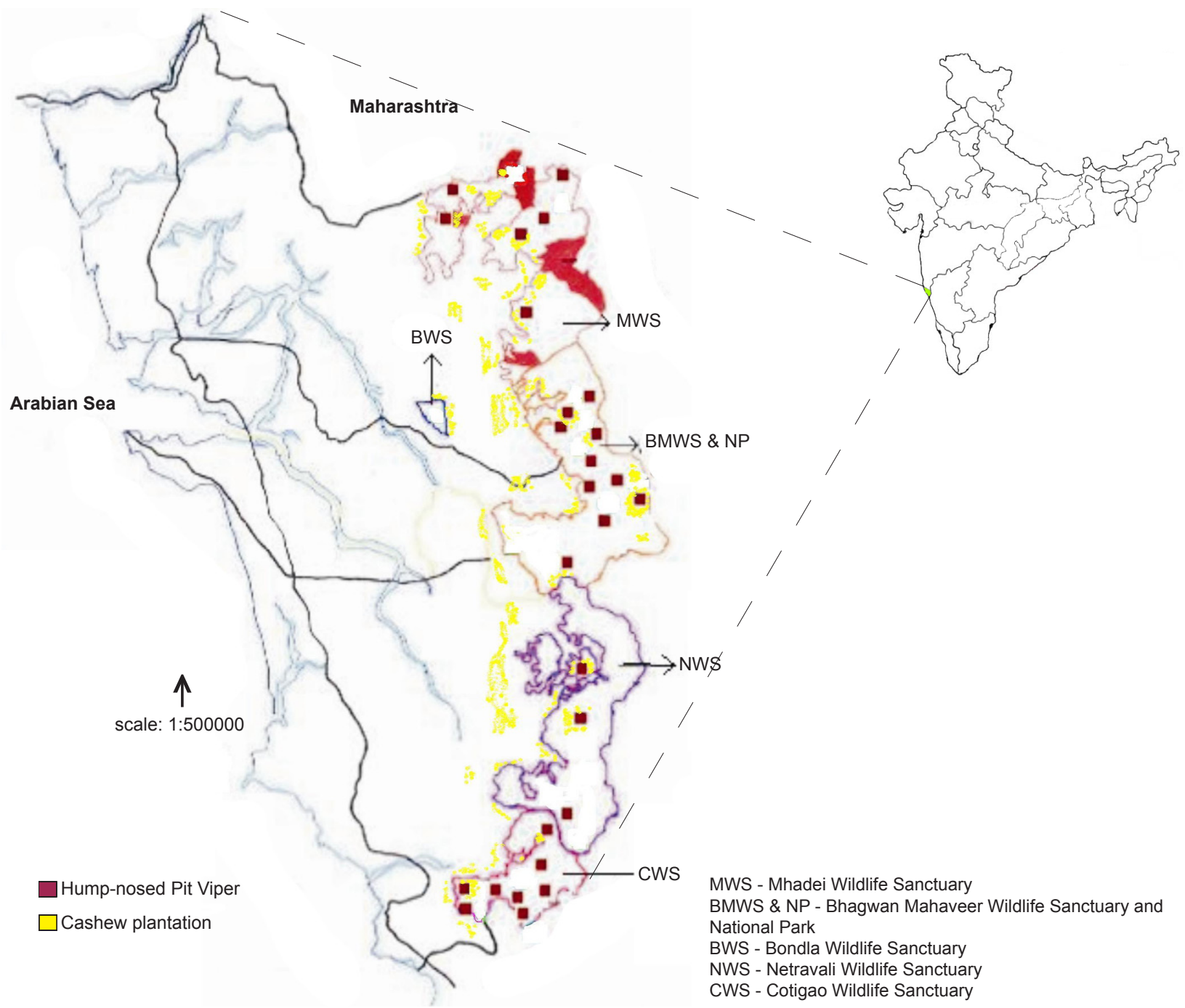

Figure 1. Distribution of Hypnale hypnale in the study sites and cashew plantations. 
1993; Reinert 1993).

The habitat of $H$. hypnale in Goa (Western Ghats region) is vulnerable to several threats including climate change and anthropogenic threats, thus it is important to identify its macro and micro-habitat. Only limited information is available on the ecology of this snake and the studies of its spatial ecology have never been conducted. Thus, this study was undertaken to study the habitat of this species, seasonal variation in habitat use, to identify the threats and device strategies for the conservation of its habitat and population.

\section{MATERIALS AND METHODS}

The sites selected for the present study were the PAs in Goa which form a part of northern Western Ghats and run in a north-south direction (Fig. 1). The sites selected were Mhadei Wildlife Sanctuary (MWS), Bhagwan Mahaveer Wildlife Sanctuary and National Park (BMWS \& NP), Bondla Wildlife Sanctuary (BWS), Netravali Wildlife Sanctuary (NWS), Cotigao Wildlife Sanctuary (CWS) and the cashew (Anacardium occidentale) plantations within and adjoining these PAs. The study sites lie at an average altitude of 20 to $800 \mathrm{~m}$ (from south to north).

Intensive surveys on foot were carried out in the Western Ghats region, from June 2005 to January 2009, in the five sanctuaries mentioned above. The possible habitat sites of $H$. hypnale were marked with band transects. An average path or road of $2.5 \mathrm{~km}$ length was considered with a width of $20 \mathrm{~m}$ ( $10 \mathrm{~m}$ on both side of the transect). The distribution of $H$. hypnale was recorded using the transect sampling method as described in Dahanukar \& Padhey (2005). Geographical positioning of the each location was obtained by hand-held Geographical Positioning System (GPS). Humidity and temperature were also recorded using a hygrometer and a mercury thermometer. In the cashew plantations the temperature and humidity of the leaf litter core was also recorded.

The transects were monitored regularly during day and night hours in different seasons and local inputs (secondary data) were also recorded. The survey involved an active search i.e. close visual inspection of shrubs, trees, ground, leaf litters. Secondary data included the collection of $H$. hypnale from local people (live \& occasionally dead). During the survey the threats to this snake population and its habitat were also identified. The snakes were collected by snake sticks. All the snakes encountered during the survey were identified up to species level following the methodology of Smith (1943), Murthy (1989), and Daniel (2002). The number of snakes and their sex was recorded.

The data recorded from transects was used to estimate the species distribution in each study area. The data was also used to find the abundance of the species during different seasons. Variance among the abundance of the $H$. hypnale in study sites (forest area and cashew plantation) during different seasons (summer, monsoon, post monsoon and winter) was tested using the oneway ANOVA. Difference of $p<0.05$ was regarded as statistically significant. All the calculations were carried out using the Microsoft Excel Software 2007.

\section{RESULTS}

In the present study, H. hypnale (Image 1) was found to occur in all of the study sites surveyed except in BWS (Fig. 1). Incidentally, locals have reported sighting of this species in precincts of BWS. The average temperature in all the study areas ranged from $20.88 \pm 5.25{ }^{\circ} \mathrm{C}$ to 32.44 $\pm 0.88^{\circ} \mathrm{C}$. Whereas the humidity ranged from $53 \pm 4$ $\%$ to $93 \pm 2 \%$. GPS records showed that $H$. hypnale was found at an altitude range of 35 to $627 \mathrm{~m}$. It was observed that amongst the forest types present in the PAs of Goa, the $H$. hypnale preferred the west coast tropical evergreen, cane brakes, moist bamboo brakes, slightly moist teak forest, southern moist deciduous forests, south Indian sub-tropical savannah woodland, and southern sub-tropical hill type. During the present study, it was observed that the $H$. hypnale is an ambush predator and wiggles its tail to attract the prey, on some occasions it was encountered feeding on sinks, frogs and agamids. The predators of $H$. hypnale include predators such as the Crested Serpent-eagle, coucal, peacock and cobra which were sighted preying on $\mathrm{H}$. hypnale; other potential predators include shikra, vipers, mongoose and civet cats. The same was also reported by locals. The list of floral and faunal associates of the $H$. hypnale is given in (Table 1). In most of the sightings the $H$. hypnale was found on the ground beneath the leaf litter. However, occasionally it was found on shrubs and herbs at an average height of up to $1.3 \mathrm{ft}$ from the ground. It was also noted that during the post monsoons, winters and late summers the $H$. hypnale moved to the adjoining cashew plantations. The number of individuals sighted in the forest area and

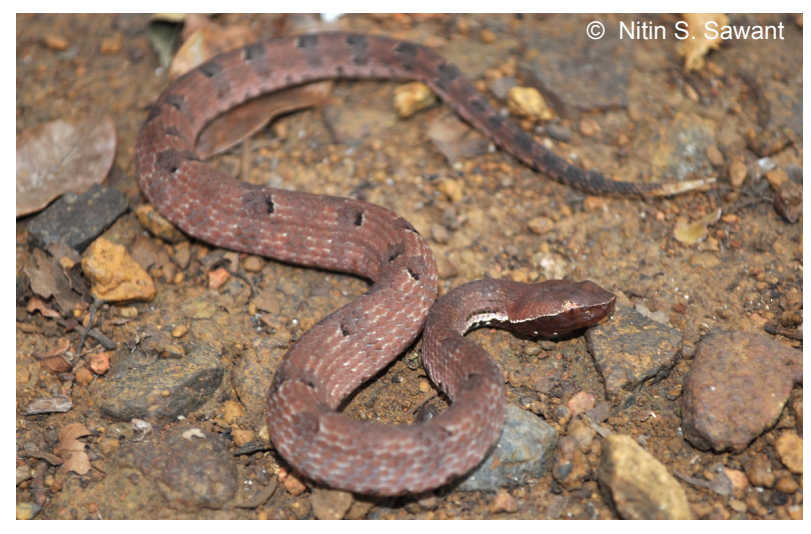

Image 1. Hypnale hypnale in natural habitat 
Table 1. List of floral and faunal associates of $\boldsymbol{H}$. hypnale.

\begin{tabular}{|c|c|}
\hline List of flora & List of fauna \\
\hline Trees & Mammals \\
\hline Tectona grandis & Muntiacus muntjak \\
\hline Terminalia alata & Viverricula indica \\
\hline Terminalia arjuna & Paradoxurus hermaphroditus \\
\hline Terminalia tomentosa & Axis axis \\
\hline Terminalia chebula & Tragulus meminna \\
\hline Terminalia crenulata & Pteropus giganteus \\
\hline Terminalis paniculata & Bos gaurus \\
\hline Terminalia bellirica & Lepus nigrocollis \\
\hline Xylia xylocarpa & Canis aureus \\
\hline Saraca asoca & Macaca radiata \\
\hline Careya arborea & Felis bengalensis \\
\hline Tabernaemontana heyneana & Rusa unicolor \\
\hline Strychnos nux-vomica & Hystrix indica \\
\hline Grewia tiliaefolia & Reptiles \\
\hline Lagerstroemia speciosa & Calotes versicolor \\
\hline Eupatorium odoratum & Calotes rouxi \\
\hline Anacardium occidentale & Naja naja \\
\hline Calycopteris floribunda & Ophiophagus hannah \\
\hline Shrubs & Cyrtodactylus dekkanensis \\
\hline Rauvolfia serpentina & Hemidactylus brooki \\
\hline Leea indica & Xenochrophis piscator \\
\hline Vitex negundo & Macropisthodon plumbicolor \\
\hline Mussaenda glabra & Bungarus caeruleus \\
\hline Herbs & Draco dussumieri \\
\hline Eupatorium sp. & Python molurus \\
\hline Gloriosa superba & Varanus bengalensis \\
\hline Grasses & Eutropis carinata \\
\hline Arundinella leptochloa & Riopa punctata \\
\hline Bambusa arundinacea & Trimeresurus gramineus \\
\hline Cynodon dactylon & Vipera russelli \\
\hline \multirow[t]{18}{*}{ Cyperus rotundus } & Echis carinatus \\
\hline & Trimeresurus malabaricus \\
\hline & Aves \\
\hline & Strix ocellata \\
\hline & Pavo cristatus \\
\hline & Accipiter badius \\
\hline & Amphibians \\
\hline & Hoplobatrachus tigerinus \\
\hline & Hoplobatrachus crassus \\
\hline & Indirana beddomii \\
\hline & Fejervarya sp. \\
\hline & Fejervarya keralensis \\
\hline & Fejervarya rufescens \\
\hline & Euphlyctis cyanophlyctis \\
\hline & Sphaerotheca rolandae \\
\hline & Sphaerotheca breviceps \\
\hline & Ramanella montana \\
\hline & Sphaerotheca leucorhyncus \\
\hline
\end{tabular}

the cashew plantation during different seasons is given in Fig. 2. The Analysis of Variance (i.e. one-way ANOVA) for testing the abundance of $H$. hypnale for forest area with respect to different seasons showed that $p=0.254$, $\mathrm{df}=3, \mathrm{~F}=1.539$, whereas, the one-way ANOVA to test the abundance of $H$. hypnale for the cashew plantation with respect to different seasons showed that $p=0.227$, df $=$ $3, F=1.66$.

It was noted that the population which moved to the adjoining cashew plantations had low male: female ratio i.e. 0.227. It was also seen that most of the females that moved to the cashew plantations were gravid females. Thus, $65.9 \%$ of the total females sighted in the cashew plantations were gravid females. The temperature of the leaf litter core was $1.96 \pm 1.32{ }^{\circ} \mathrm{C}$ lower than the ambient temperature, whereas the humidity was $5 \pm 1.87 \%$ higher than ambient humidity as compared to the forest area where the leaf litter temperature was $0.42 \pm 0.13^{\circ} \mathrm{C}$ lower and humidity was $1.8 \pm 0.83 \%$, higher than the ambient temperature and humidity during the post monsoon and winter seasons. During the present study the following threats were identified.

(i) Habitat fragmentation due to encroachment and mining activities due to which most of the areas neighbouring the protected areas are affected.

(ii) The increasing population of peacocks might have put immense pressure on the population of the $H$. hypnale as it is one of the dominant predators found in all the study sites.

(iii) The major threat faced by the $H$. hypnale population is the anthropogenic pressure, especially due to their shift in habitat to the cashew plantations during the post monsoon and winter where they are killed out of fear by the labourers during the clearance of shrubs in the cashew plantations (Image 2).

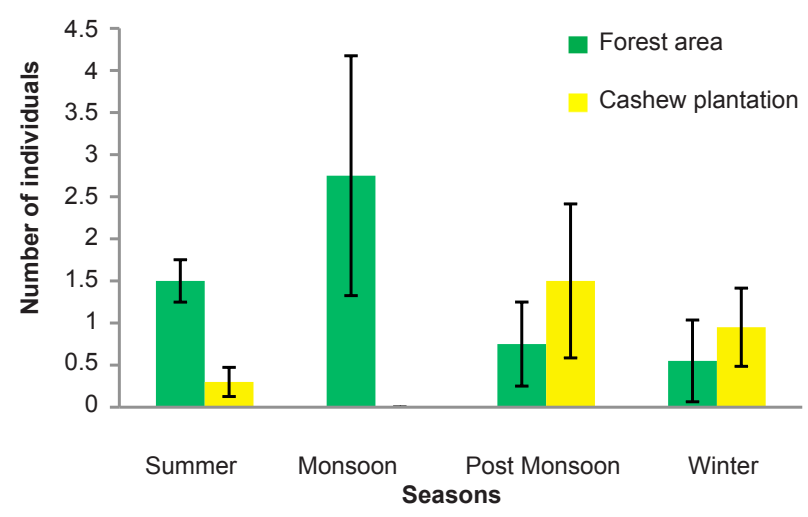

Figure 2. Average Number of individuals \pm SE sighted in the forest area and cashew plantations during different seasons. 


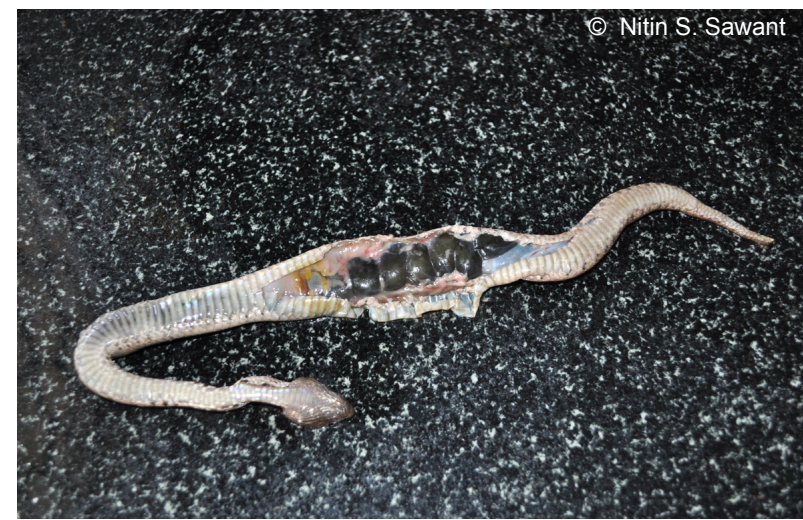

Image 2. Gravid female killed in cashew plantation during weed clearance

\section{DISCUSSION}

Habitat destruction is the major cause of endangerment for many of the world's threatened species (Losos et al. 1995; Fahrig 1997). It is therefore important to identify the habitats utilized by this species of pit viper and to protect the habitat relevant for their conservation. Identifying the habitat requirement, activity pattern and spatial distribution of a species is important towards the ecological management of this specie's population and habitats.

The present study revealed that the $H$. hypnale is in the Western Ghats (India) and distributed in parts of Maharashtra, Goa and southern parts of India. We observed that the $H$. hypnale preferred most of the forest type present in the protected areas of Goa. However, during the present study there was no record of the $H$. hypnale in the BWS. Incidentally, the locals reported the presence of $H$. hypnale in the vicinity of BWS. It is the smallest wildlife sanctuary of Goa and amongst the forest type preferred by the $H$. hypnale, only cane brakes, wet bamboo brakes, southern secondary moist mixed forest and west coast semi-evergreen, moist bamboo brakes and lateritic semi evergreen forest patches prevail in BWS. A possible factor which has affected this species may be the presence of a zoological garden in the sanctuary which attracts many tourists and a continuous flow of vehicles which causes disturbances of the habitat. Secondly this species shows a shift in habitat during different seasons, for which the hygrothermal profile such as cool and moist climate, leaf litter, suitable retreat and breeding site is not available at BWS throughout the year.

We observed that the $H$. hypnale occupied a broader altitudinal range (35 to $637 \mathrm{~m}$ ) which suggests that factors such as temperature, humidity, basking sites and prey availability play a major role in habitat selection. These observations are in agreement with the report of Dial (1978), Huey et al. (1989), Madsen \& Shine (1996), Kearney (2002), and Pringle et al. (2003). Hypnale hypnale is mostly terrestrial but has occasionally been encountered on herbs and shrubs; this excursion is obviously a part of the process of thermo-regulation. Shine et al. (2005) believed that climbing above ground level to facilitate thermo-regulation is widespread in snakes as in other ectotherms.

During the present study, it was observed that the $H$. hypnale showed a shift in habitat from natural confines within the protected areas into the cashew plantations. There are no previous records of such a shift in habitat shown by the $H$. hypnale. Interestingly, such a shift in habitat coincides with the breeding season and these interim movements are mostly exhibited by the females, especially by the gravid females. Males were very rarely encountered in the cashew plantations. The transient shift by the gravid females into the cashew monoculture merits discussion. The micro habitat requirement of the breeding individuals is perhaps best met in the cashew plantation owing to the density and thickness of the leaf litter. Reinert (1993) suggested that the need to locate essential resources such as food, shelter and gestation sites, influences habitat selection by snakes. A few studies (Houston \& Shine 1994; Mullin \& Cooper 2000; Shine \& Sun 2002) showed that reptiles prefer habitat with a high prey abundance. Janzen \& Schoener (1968) suggested that factors such as general reduction in the forest productivity in the dry seasons affect most animals including reptiles and their prey. Thus, less prey availability is the possible reason for the shift in habitat from the forest area to the cashew plantation. This also explains why there is a difference in sightings during different seasons. Henderson et al. (1979) reported that the effect of rainfall on snake activity may be indirect by affecting prey availability. The present study revealed that leaf litter core temperature was $1.96 \pm 1.32^{\circ} \mathrm{C}$ lower than the ambient temperature, whereas the humidity was $5 \pm 1.87 \%$ higher than ambient humidity in the cashew plantation as compared to the forest area. This cool and humid climate below the leaf litter provides a good micro-climate for reptiles which is the major prey base for the reptiles. This in turn forms the prey base for the $H$. hypnale. This is supported by Kumar et al. (2001). Lima \& Dill (1990) suggest that specific features of the leaf litter help reptiles to meet the conflicting demands of thermoregulation, predator avoidance and participation in other activities.

Hypnale hypnale is a species of Western Ghats (India) and faces tremendous anthropogenic pressure. Habitat fragmentation due to mining activities around the protected areas is the immediate threat to this species. $H$. hypnale is a terrestrial species and ambush predator, which requires habitat such as a favourable hygrothermal profile, thick and moist leaf litter etc. The increase in avian predators such as the peacock has drastically reduced the population of this species and other reptiles and amphibians in some areas. During the post monsoon and winter periods, ground clearance in the cashew plantation 
is carried out to allow free movement under the plantation for cashew collection. During this process $H$. hypnale are encountered under small bushes and thick leaf litter. Thus this behavior of shifting habitat, especially by the gravid females to the cashew plantations is a cause of concern from the conservationist's point of view since the work force employed for such massive clearance, kills the snake out of fear. Such phenomenon is not uncommon in some parts of Goa, especially in places such as Sattari and Sanguem, and necessitates a conscious effort of educating the workers, on the conservation importance of these reptiles. Goa is a small state and mining is a major source of income for the state, most of the mining leases are around the protected areas, thus it has become very difficult to protect the habitat of this species. It is, therefore, important to create awareness among the communities to protect the habitat in order to protect these species. The government agencies (policy makers) play a vital role in directly conserving the habitat of the species, which in turn can aid in the indirect conservation of this species which is endemic in the Western Ghats and Sri Lanka.

\section{REFERENCES}

Bhupathy S. \& P. Kannan (1997). Status of Agamid Lizards in the Western Ghats of Tamil Nadu, India, Technical Report No. 5. Coimbatore: Salim Ali Centre for Ornithology and Natural History Brooks.T.M., S.L. Pimm \& J.O. Oyugi (1999). 'Time lag between deforestation and bird extinction in tropical forest fragments', Conservation Biology 13: 1140-50.

Burger, J. \& R.T. Zappalorti (1988). Habitat use in free ranging pine snake, Pituophis melanoleucus, in the New Jersy Pine Barrens. Herpetologica 44: 48-55.

Champion, H.G. \& S.K. Seth (1968). A Revised Survey of the Forest Types of India, Delhi: Government of India Press, 404pp.

Dahanukar, N. \& A. Padhye (2005). Amphibian diversity and distribution in Tamhini, northern Western Ghats, India. Current Science 88: 1496-1501.

Daniel, J.C. (2002). The Book of Indian Reptiles \& Amphibians. Oxford University Press, New Delhi, 238pp.

Dial, B.E. (1978). The thermal ecology of two sympatric nocturnal Coleonyx (Lacertilia: Gekkonidae). Herpetologica 32: 194201.

Dodd Jr. C.K (1987). Status, conservation and management, pp. 478-513. In: Seigel, R.A., J.T. Collins \& S.S. Novak (eds). Snake: Ecology and Evolutionary Biology. McGraw-Hill, New York, 529pp.

Dodd Jr. C.K. (1993). Strategies for Snake Conservation, pp. 363-393. In: Seigel, R.A., J.T. Collins, \& S.S. Novak (eds). Snake: Ecology and Behaviour. McGraw-Hill, New York, 414pp.

Fahrig, L. (1997). Relative effects of habitat loss and fragmentation on population extinction. Journal of Wildlife Management 61: 603-610.

Gadgil, M. \& R. Guha (1992). This Fissured Land: An Ecological history of India. Oxford University Press, pp.113-140.

Gurnell, J., M.J. Clark, P.W.W. Lurz, M.D.F. Shirley \& S.P. Rushton (2002). Conserving red squirrels (Sciurus vulgaris): mapping and forecasting habitat suitability using a Geographic Information Systems approach. Biological Conservation 105: 53-64.
Heatwole, H.F. (1977). Habitat selection in reptiles, pp. 137-155. In: Gans, C. \& D.W. Tinkle (eds). Biology of Reptilia: Ecology and Behaviour, Academic press, London, 720pp.

Henderson, R.W., J.R. Dixon \& P. Soini (1979). Resource partitioning in Amazonian snake communities, Milwaukee Pub, Mus. Contributions in Biology \& Geology 22: 1-11.

Houston, D.L. \& R. Shine (1994). Movements and activity patterns of arafura filesnakes (Serpentes: Acrochrordidae) in tropical Australia. Herpetplogica 50: 349-357.

Huey, R.B., C.R. Peterson, S.J. Arnold \& W.P. Porter (1989). Hot rocks and not so hot rocks: Retreat site selection by garter snakes and its thermal consequences. Ecology 70 : 931-944.

Inger, R.F., H.B.M. Shaffer \& R. Bakde (1987). Ecological structure of a herpetological assemblage in south India. Amphibia-Reptilia 8: 189-202.

Janzen, D.H \& T.W. Schoener (1968). Differences in insect abundance and diversity between wetter and drier sites during a tropical dry season. Ecology 49: 96-110.

Joshi, V.C. \& M.K. Janarthanam (2004). The diversity of life forms type, habitat preference \& phenology of the endemics in the Goa region of Western Ghats, India. Journal of Biogeography 31: 1227-1237.

Kearney, M. (2002). Hot Rocks and Much-too- hot rocks: Seasonal patterns of retreat-site selection by nocturnal ectotherms. Journal of Thermal Biology 27(3): 205-218.

Khaire, N. (2006). A Guide to the Snakes of Maharashtra, Goa and Karnataka. Indian Herpetological Society. 'USANT', Maharashtra, India, 104-114pp.

Kumar, A., S. Walker \& S. Molur (1998). Prioritization of endangered species. Report submitted to World Wildlife Fund for Nature-India.

Kumar, A., R. Chellam, B.C. Choudhary, D. Mundappa, K. Vasudevan, N.M. Ishwar \& B. Noon (2001). Impact of rainforest fragmentation on small mammals and herpetofauna in the Western Ghats, South India. Final Project report Wildlife Institute of India, Dehradun.

Lima, S.L. \& L.M. Dill (1990). Behavioral Decisions made under the risk of predation: a review \& prospectus. Canadian Journal of Zoology 68: 619-640.

Losos, E., J. Hayes, A. Philips, D. Wilcove \& C. Alkire (1995). Taxpayer-subsidized resource extraction harms species: double jeopardy. Bioscience 45: 446-455.

Madsen, T. \& R. Shine (1996). Seasonal migration of predators and prey- a study of pythons and rats in tropical Australia. Ecology 77: 149-156.

Maduwage, K., A. Silva, K.M. Arachchi \& R. Pethiyagoda (2009). A taxonomic revision of the South Asian hump-nosed pit vipers (Squamata: Viperidae: Hypnale). Zootaxa 2232: $1-28$

Mittermeier, R.A., J.L Carr, I.R. Swingland, T.B. Werener \& R.B. Mast (1992). Conservation of amphibians and reptiles, pp 59-80. In: Adler, K. (ed.). Herpetology: Current Research on The Biology of Amphibians and Reptiles. Proceedings of the First world Congress of Herpetology. Society for the study of amphibians and reptiles, Oxford Press, Ohio.

Mullin S.J. \& R.J. Cooper (2000). The foraging ecology of the gray rat snake (Elaphe obsoleta spiloides). II. Influence of habitat structural complexity when searching for arboreal avian prey. Amphibia-Reptilia 21: 211-222.

Murthy, T.S.N. (1990). Records of the Zoological Survey of India: Illustrated Guide to The Snakes of The Western Ghats, India. Zoological Survey of India, Calcutta, 58-63pp.

Nair, S.C. (1991). The Southern Western Ghats: A Biodiversity Conservation Plan. INTACH, New Delhi, 92pp.

Pradhan, M.S. (2008). Reptilia, pp. 281-364. In: Fauna of Goa, State Fauna Series, (ed. Director), Zoological Survey of India, $531 \mathrm{pp}$.

Pringle, R.M., J.K. Webb, R. Shine (2003). Canopy structure, 
microclimate, and habitat selection by a nocturnal snake, Hoplocephalus bungaroides. Ecology 84: 2668-2679.

Reinert, H.K. (1984). Habitat separation between sympatric snake populations. Ecology 65:478-486.

Reinert, H.K. (1993). Habitat Selection in Snakes, pp. 201-233. In: Seigel, R.A., \& J.T. Collins (eds). Snakes: Ecology and Behaviour, McGraw-Hill Inc New York, 414pp.

Sawant, N.S., T.D. Jadhav \& S.K. Shyama (2010). Distribution and abundance of pit vipers (Reptilia: Viperidae) along the Western Ghats of Goa, India. Journal of Threatened Taxa 2(10): 1199-1204.

Schoener, T.W (1977). Competition and Niche, pp. 35-136. In: Gans, C. \& D.W. Tinkle (eds). Biology of the Reptilia - Vol 7. Academic, New York, 720pp.

Shine, R. \& L. Sun (2002). Ambush-site selection by pit-viper (Gloydius shedaoensis). Animal Behaviour 63: 565-576.

Shine, R., M. Wall, T. Langkilde \& R.T. Mason (2005). Scaling the heights: thermally driven arboreality in garter snakes. Journal of Thermal Biology 30: 179-185.
Smith, M.A. (1943). Reptiles and Amphibia: The fauna of British India, Ceylon and Burma, Vol III - Serpentes. Today \& Tommorow's Priters \& Publishers, New Delhi, 494-526pp.

Toft, C.A. (1985). Resource partitioning in amphibians and Reptiles. Copeia 1-21.

Weatherhead, P.J. \& M.B. Charland (1985). Habitat Selection in an Ontario population of the snake, Elaphe obsoleta. Journal of Herpetology 19: 12-19.

Weatherhead, P.J. \& K.A. Prior (1992). Preliminary observation of habitat use and movements of the eastern Massasauga rattlesnake (Sistrurus c. catenatus), Journal of Herpetology 26: 47-452.

Whittaker, R.H., S.A. Levin \& R.B. Root (1973). Niche, Habitat and Ecotope. The American Naturalist 107: 321-338.

Whitaker, R. (1978). Common Indian Snakes: A Field Guide. Macmillan India Limited, New Delhi, 154pp.

Wilson, E.O. (1992). The Diversity of Life. W.W. Norton, New York, USA, 434pp. 